\title{
Lembrar, esquecer, censurar
}

\author{
RUI TAVARES
}

La mémoire est nécessaire pour toutes les opérations de la raison.

Pascal, Pensées, 651-369 (1)

Había aprendido sin esfuerzo el inglés, el francés, el portugués, el latín. Sospecho, sin embargo, que no era muy capaz de pensar. Pensar es olvidar diferencias, es generalizar, abstraer. En el abarrotado mundo de Funes no había sino detalles, casi inmediatos. Borges, Funes el memorioso, in Ficciones (2)

\section{A Real Mesa Censória sob Pombal (Portugal, 1768-1777)}

$\mathrm{N}$

O INÍCIO DE 1777, poucos meses antes da morte de D. José I e da queda do marquês de Pombal, um censor de nome António de Santa Marta Lobo da Cunha estava encarregado de examinar um livro impresso em Londres e "escripto na Lingua Franceza". O título desse livro era L'An deux mille quatre cents quarante.

A sua censura foi entregue no dia 13 de janeiro. Eram quatro páginas de caligrafia cuidadosa terminadas na véspera, nas quais o censor enumerara os defeitos da obra de forma sistemática e inequívoca (3).

Existem muitas outras censuras em que se sente - por detrás de uma reprovação devida, burocrática, do censor - um tom de mal disfarçada admiração pelo virtuosismo do autor ou mesmo de interesse pelo conteúdo da obra. Não é, de todo, este o caso presente. O censor limita-se a abrir uma pequena excepção, condicional, para a originalidade da ideia que deu origem ao livro; mas o autor, mais que não a saber aproveitar, levou-a por caminhos condenáveis:

"Porque quando a idea que se propós indicava hum bom filozofo, e ingenhoso Critico, acho que a doutrina toda he de um Deista extravagante e Monarchomaco reforçado.”

Resistamos por agora à tentação de comentar esta frase e nomeadamente de nos perguntarmos que fazem aqui estes dois termos, "crítico" e, acima de tudo, "filósofo", empregue de forma não-pejorativa, e deixemos o censor explicar-se melhor: 
"Para o seu Author formar o plano desta Obra entrou no enthusiasmo de suppor hum sonho em que se transportou no anno de 1740, do qual veio a acordar no de 2440 para ter 700 anos, e então poder achar, e ver o mundo reformado. Mas pensando eu, e devendo esperarse deste artificio em que se vale do Lemma de Leibnitz $=\mathrm{O}$ tempo prezente está prenhe do que está para vir $=$, que elle se quizesse reppor naquella idade tão apartada do tempo em que escreve, para com liberdade de criterio rediculizar os abusos, e prejuizos do nosso Seculo, e inventar esta reforma regulada pelas Leis da boa razão, elle se não esforsa mais, que em amoldalla á medida do seo appetite, e da sua falsa Religião.”

Estes são os dois parágrafos iniciais da censura, nos quais o censor faz questão de deixar claro tudo o que o divide do autor. A boa ideia de que este partiu, uma viagem de 700 anos no futuro, é o breve ponto de partida em que os dois coincidem. A partir daqui, os caminhos separam-se e um fosso se cava entre eles. Após acusar o autor de "deísta extravagante, e monarcómaco reforçado", o censor concretiza as suas acusações:

“...o objecto principal he declamar contra o governo Monarchico, insultando o seo despotismo, e julgando todas as suas Leis contrarias á razão, e á natureza. E a doutrina em tudo o que respeita á religião, a encontra: desprezando em repetidas paçagens os uzos, e costumes, que dizem respeito ao Christianismo. Lerei algumas. No Cap. 19 que intitula Le Temple, pag. 115 lin. 18 dis 'Que não há outra religião, que a de Adam, e Enoc, que adoravam a Deos em espirito no cimo dos montes, Lei, e Religião Simplicissima' e conclue: 'Todo o resto he impostura, falacia, engano'. No Cap. 28 La Bibliotheque du Roi fl. 197 lin. 26 Reprova a doutrina dos Padres da Igreja para adoptar huma corja de libertinos. Cap. XV Theologie, e Jurisprudence fl. 72 1. 3 Exclama contra os Livros theologicos chamandolhes massas informes, e pezos das livrarias; e na $\mathrm{I}^{\text {a }}$ nota diz 'Os Moralistas são benfeitores do genero humano, e os theologos o seo opprobio, e loucura.' O Cap. 17 todo he huma Invectiva contra o Estado Religioso suppondo a todos, que o professam, privados de toda a sua felicidade, que elle repoem em poderem cazar: elle faz huma pintura a mais sacrilega de todas as Familias Religiosas, dando huma idea que elles são o fruto do 'Molinismo', e 'Jansenismo'. Chama aos votos religiozos 'votos de não ser homem,' e logo os retrata arrependidos, e malancolicos na dezesperação de perderem a felicidade do estado mais doce, qual he a vida social, e para confirmar toda esta Luxúriosa invectiva se serve da authoridade 
de Luthero dizendo na $l^{\text {a }}$ nota 'Luthero' com a sua eloquencia ardente declama contra os votos religiosos, dizendo que o mesmo he votar continencia, que aniqhilar o proprio sexo'.”

A doutrina religiosa do autor é, por si só, mais do que reprovável. Também em termos morais o censor encontra motivos dignos de nota, a começar pela defesa do divórcio. Como se não bastassem estes factos, o censor vê-se na obrigação de denunciar os descarados insultos de que é objecto o Papa, considerado uma figura supérflua, que "serve só para expedição de Bullas [e] Beneficios”.

Não ficamos por aqui: o censor encontra, a cada passo, o livro infectado de conteúdos intoleráveis. L'an 2440 parece quase ser uma obra escrita intencionalmente como catálogo de proposições condenáveis, uma espécie de pesadelo do censor pombalino tornado realidade, o que se torna especialmente claro quando o autor ataca nervosamente o absolutismo de Luís XIV, tão emulado pelo pombalismo como modelo da verdadeira soberania monárquica:

"Da mesma sorte o objecto de sua obra he querer, que o mundo aparessa reformado naquelle supposto anno de 2440 ensinando aos homens a sacudir o jugo da Soberania, e as suas leis, as quais Caretheriza de dispotismo, e escravidão: para o que declama na pag. 66 em a $1^{\text {a }}$ nota Contra Richelieu, que suppoem principal factor de similhante governo na França e que hoje domina toda a Europa, dizendo 'Cruel Richelieu triste Author de todos nossos malles, que depois de destronar a Luiz 13 introduziste o dispotismo na França: desde então nada sobrou digno da Nação, porque fabricou hum Povo todo escravo.' E finalmente o Cap. 36 'Forma de gouvernement' [ sic] a fls. 286 he uma idea tiranica do governo Monarchico."

Chegados a este ponto, e ainda que volte a abrir-se uma pequena e duvidosa excepção para um juizo positivo em termos estilísticos,

"Não há duvida, que tem pelo discurço da obra algumas paçagens sofriveis pelo concertado da fraze... mas ainda estas vem tão interpoladas com praticas, e notas extensissimas, que perdem a naturalidade e graça da invensão: excedendo o lamento da obra ao estillo d'ella."

não pode haver dúvidas para o censor sobre o destino do livro. Lobo da Cunha termina então a sua censura: 
"Do que se mostra, que esta obra he daquellas que mais directamente atacam a Religião, e o Estado com propozições Ereticas, Sacrilegas, e blasfemas: maximas impias, e temerarias e que deve ser prohibida a sua leitura, pondose este Livro no numero dos prohibidos dos Editais desta Meza: Este he o meo Sentimento. Os deputados Adjuntos e toda a Meza foi do mesmo paresser."

O plenário dos deputados da Real Mesa Censória deliberou contudo que a simples proibição da obra não bastava, tal como não bastava a sua inclusão no index da instituição. Ao final da censura de Lobo da Cunha foi então acrescentada a decisão definitiva:

"Votou finalmente a Meza uniformemente que se queimasse este Livro. Meza Lxa. 13 de Janeiro de 1777.”

Já uns anos antes a Real Mesa Censória decidira mandar queimar outro livro. Desse livro existe também a censura realizada por um deputado da instituição, o censor Joaquim de Santana, em abril de 1772 (4).

Formalmente, trata-se de um documento bastante distinto do anterior. Com 30 páginas manuscritas, a censura é mais extensa do que o próprio texto que era suposto examinar. Inicia-se com uma página de rosto que mimetiza o formato do impresso. No segundo fólio, uma epígrafe retirada de Sto. Agostinho:

"Nemo vos fallat; non nuntiatum est alicui genti hoc judiciam Dei, quomodo patientur et justi, et injusti” (5).

Além destes detalhes pouco comuns em documentos do género, esta censura possui várias outras características formais bastante curiosas, como a utilização de diferentes tamanhos de letras no início de secções do texto, o aparecimento de algumas convenções, como a repetição abaixo da última linha de uma página da palavra ou fragmento de palavra que iniciará a página seguinte, ou o destaque graficamente concedido ao aparecimento das proposições ou demonstrações. A elas poder-se-ia acrescentar o critério com que se assinalam as citações, referências a títulos de obras ou a utilização de palavras estrangeiras através de sublinhados, ao passo que a localização das referências é sempre fornecida de forma pormenorizada, seja em nota à margem seja no corpo do texto. Estas características, não sendo propriamente invulgares numa censura da época, encontram-se aqui aplicadas de forma muito criteriosa, apontando para 
um extremo cuidado na preparação do texto. À primeira vista, dir-se-ia mesmo um texto de amanuense pronto a apresentar à censura e a entrar no prelo. Mas se se trata, pelo contrário, de uma censura de um texto - e por sinal uma censura que, por força do regimento da instituição que a produzira, deveria permanecer secreta -, que outras razões poderão contribuir para explicar o cuidado posto nesta emulação das características formais do livro impresso?

"Eu fui encarregado de examinar, e interpor o meu parecer sobre o Papel, que tem por titulo = Juizo da verdadeira causa do Terremoto, que padeceo a Corte de Lisboa, no primeiro de Novembro de 1755 = Author, Gabriel Malagrida Jesuita: cujo papel foi impresso em Lisboa, na officina de Manoel Soares, anno de 1756.

Este infame, malicioso, temerario, e heretico papel, que ainda lido em outros tempos, não faria impressão alguma sensivel nos homens verdadeiramente sabios, e pios, livres de illusões, e preocupações fanaticas; no tempo, no qual por merce, e graça do Altissimo a Nação Portugueza tem chegado a hum gráo superior de illuminação; e muito mais estando instruida pela sabia, e rectissima Sentença da Regia Meza do Santo Officio, a qual deo a conhecer a todo o Mundo, que monstro foi o [rasurado: impostor e] Heresiarca Gabriel Malagrida; qual sua falsa Religião; quaes suas preversas, maliciosas, e sempre temporaes intenções; só poderá servir de objecto de irrisão, e de huma prova ultima para completamente se conhecer a ignorancia, a hipocresia, a ambição, e a malicia do sobredito herege."

Uma das primeiras explicações que o próprio documento oferece a esta pergunta é a de que, ao contrário do que era habitual, o censor não estava neste caso a decidir da atribuição de licença de impressão a um texto manuscrito, mas a examinar um livro já impresso no próprio reino. Trata-se de um facto pouco comum, pois em princípio os censores não examinavam livros impressos a não ser que se tratassem de livros importados do estrangeiro. Quanto à produção nacional, o papel do censor era autorizar ou não os manuscritos a chegarem à impressão, que não podia ser feita sem licença régia (6). Estas diferenças têm a sua importância, pois a censura de um impresso ou de um manuscrito são trabalhos de naturezas muito distintas. A intervenção do censor no conteúdo de um impresso (através, por exemplo, da rasura de determinadas passagens em todos os exemplares de um livro) é bastante inconveniente e acima de tudo muito menos discreta do que no caso de um manuscrito, onde o censor pode suprimir ou alterar passagens do texto de forma virtualmente 
imperceptível para o leitor. Nos impressos, o censor fica assim limitado a duas alternativas extremas: licenciar ou permitir. A opção pelo meio termo é difícil.

O que mais parece ter interpelado o censor neste caso, porém, é o facto de um livro nos falar a partir de uma posição completamente diferente da de um manuscrito. A autoridade que emana de um texto impresso ou de um texto manuscrito é muito diferente - e o censor sabe disso melhor do que ninguém, uma vez que a ele cabe decidir da concessão ou não do acesso à autoridade do impresso. Torna-se pois compreensível que Joaquim de Santana (ou, quem sabe, a própria Real Mesa Censória) se tenha esforçado para que esta censura ao Juizo da verdadeira causa do terremoto estivesse à altura do livro que devia examinar, que lhe pudesse responder a partir de uma posição de valor idêntico. A censura está intimamente relacionada com dominar o centro do debate intelectual. Mas, na época, está-o não só no sentido em que ela tem o poder para, a partir de fora, dominar esse centro, mas também porque os censores se devem legitimar por já partilharem, à partida, dessa centralidade - é a partir dela que os censores operam. O censor é (deve ser) um par que recenseia a obra de outro par. Fá-lo com poder de veto, o que faz da censura um instrumento intelectual temível - mas deve frisar-se que se trata, ainda assim, de um instrumento intelectual.

Antes de 1768, quando as censuras ainda eram impressas juntamente com a obra licenciada, os títulos do censor acompanhavam sempre o seu nome; saber se o censor pertencia à Real Academia de História de Portugal ou se era lente em Coimbra era uma garantia da legitimidade com que o censor se pronunciava sobre aquele livro. Mesmo tratando-se de uma censura posterior a essa data (e portanto, em princípio, secreta por força de lei), é natural que o censor do Juizo da verdadeira causa do terremoto procurasse legitimá-lo dando-lhe características formais próximas ao livro erudito e um tipo de explanação que, como veremos adiante, com os seus dispositivos retóricos, as suas proposições e demonstrações laboriosamente concatenadas, pretende assemelhar-se mais ao tratado do que à censura mais típica. Ao estudar a censura do Antigo Regime de um ponto de vista "micro", apercebemo-nos de como na mente destes censores o duplo sentido da palavra autoridade - autoridade política e autoridade intelectual - não constituía, muito provavelmente, duplo sentido algum. 
Ao ler aquelas primeiras palavras do censor, atrás citadas, a impressão com que imediatamente se fica é a de que este Juizo da verdadeira causa do terremoto não pode ser um livro qualquer. $\mathrm{O}$ tom do censor é extremamente violento: ainda a primeira frase da sua censura não está terminada e já o texto sob o seu exame é "infame, malicioso, temerario, e heretico". É, pois, inevitável conceder-se que se esta censura é especial é porque o próprio livro censurado é um livro especial.

E, de facto, o Juizo da verdadeira causa do terremoto tinha desempenhado um papel importante na fase de consolidação do poder do marquês de Pombal (então ainda só conde de Oeiras), após o violento sismo que destruiu Lisboa a 1 de novembro de 1755. O tê-lo escrito levou o seu autor, um jesuíta italiano que tinha passado a maior parte da sua vida no Brasil, à fogueira inquisitorial em setembro de 1761. Esta sentença, a que aliás o intróito da censura faz referência, foi a última do género a ser proferida pelo Santo Ofício, o que conferiu a Malagrida a duvidosa honra de ter sido a última vítima mortal da Inquisição portuguesa. A sua execução marcou uma etapa na escalada de hostilidade entre o pombalismo e os jesuitas, que havia de culminar na expulsão dos membros da Companhia em 1759. Todos estes acontecimentos foram acompanhados de ondas de polémica duradouras, tanto no reino como no estrangeiro (7).

Seria interessante tentar perceber porque se empenhou o pombalismo tardio e consolidado, 11 anos depois, em levar a obra ao mesmo destino que o seu autor. A produção desta censura em 1772 parece ainda mais redundante se pensarmos que, para além da condenação inquisitorial, o Juizo da verdadeira causa do terremoto se encontrava também proibido pelas disposições gerais emitidas pelo Desembargo do Paço quando da expulsão da Companhia, e que interditavam a leitura de obras jesuíticas. Embora não esteja dentro dos limites deste texto, vale a pena realizar uma breve incursão no contexto do caso Malagrida.

Desde logo, o primeiro facto interessante é o de que a edição do Juizo da verdadeira causa do terremoto em 1756 fora inteiramente legal, "com todas as licenças" (8). Na altura não existia ainda a Real Mesa Censória, o que forçara o texto a passar, como era hábito desde há mais de dois séculos, por três exames de três censores diferentes, cada um deles nomeado respectivamente pelo Desembargo do Paço, pelo “ordinário" (nome dado à censura episcopal, no caso presente a do Patriarcado de Lisboa) e pelo Santo Ofício - que pouco tempo depois haveria de condenar o autor do texto pelo texto que a própria instituição aprovara. 
A censura de Joaquim de Santana ao Juizo da verdadeira causa do terremoto constitui assim um duplo diálogo, ainda que um diálogo por omissão. Mais do que uma interpelação ao próprio autor, já morto havia 11 anos, ou ao seu livro, também já há muito condenado, trata-se de uma resposta à continuada polémica sobre a execução de Malagrida, através da produção de um documento legal que faltava na acusação. E tratase também de um diálogo (ainda que de regras viciadas) com os censores que haviam antes aprovado o livro.

Ampliando o raciocínio, poderíamos ainda identificar nela um diálogo entre dois portugais diferentes, separados por apenas uma década: o Portugal do pombalismo triunfante, que acusa esta obra de ser um "infame, malicioso, temerario, e heretico papel", obra de um "heresiarca" e "fanático" que foi "um monstro" (9) e o Portugal que antes a aprovara nestes termos:

"Li com grande gosto este papel, que vejo ser invenção, e composição do P. Gabriel Malagrida da Companhia de JESUS e varaõ bem conhecido pelos seus apostolicos empregos... reluz nelle tanto a chãma superior, que incende ao Author, que bem mostra ser forjado naquella frágoa, onde reside hum espirito... só quem vive assim, sabe formar hum juizo tão proprio das obras de Deos..." (10)

Joaquim de Santana age como se estas primeiras e positivas censuras ao texto pura e simplesmente não existissem, embora o diálogo com elas esteja subtextualmente presente no excerto inicial, já citado, em que o censor concede:

"Este infame, malicioso, temerario, e heretico papel, que ainda lido em outros tempos, não faria impressão alguma sensivel nos homens verdadeiramente sabios, e pios, livres de illusões, e preocupações fanaticas; no tempo, no qual por merce, e graça do Altissimo a Nação Portugueza tem chegado a hum gráo superior de illuminação... só poderá servir de objecto de irrisão, e de huma prova ultima para completamente se conhecer a ignorancia, a hipocresia, a ambição, e a malicia do sobredito herege.”

Nota-se nesta passagem uma certa descontinuidade entre os dois argumentos apresentados. Um não parece proceder claramente do outro: se já antes a obra não impressionaria os homens verdadeiramente sábios, porque é que ela agora o faz, se a nação chegou “a hum gráo superior de illuminação"? Por outro lado, o menosprezo com que no fim 
se trata o livro ("só poderá servir de objecto de irrisão") não se coaduna com o verdadeiro escândalo que o censor sente ante a perigosidade deste "infame, malicioso, temerario, e heretico papel". Joaquim de Santana tem evidentes dificuldades em explicar como um texto tão pernicioso e carregado de defeitos pode ao mesmo tempo ter sido indiferente a alguém.

$\mathrm{Na}$ verdade, se tentarmos ler o texto fazendo o exercício de abstrairmos dos acontecimentos posteriores à sua edição, a primeira coisa que saltará à vista é a sua banalidade. É, certamente, um texto muito devoto, o que poderá eventualmente explicar-se pelas circunstâncias em que foi editado, na sequência do terrível sismo de 1 de novembro de 1755, seguido de um maremoto e inúmeros incêndios, que praticamente destruiram a cidade de Lisboa. O texto de Malagrida assemelha-se a um sermão. Inspirando-se sucessivamente no exemplo de vários profetas, o padre toma para si o fardo de dizer à cidade qual a verdadeira causa do terrível sismo:

"Sabe pois, oh Lisboa, que os unicos destruidores de tantas casas, e Palacios, os assoladores de tantos Templos, e Conventos, homicidas de tantos seus habitadores, os incendios devoradores de tantos thesouros, os que a trazem ainda tão inquieta, e fóra da sua natural firmeza, naõ saõ Cometas, naõ saõ Estrellas, naõ saõ contigencias, ou causas naturaes; mas saõ unicamente os nossos intoleraveis peccados" (11).

Esta passagem é o motivo central do texto, bem como o da censura, onde a sua análise ocupa quase metade do documento. Ela é o crime de Malagrida: ter defendido uma explicação sobrenatural para a ocorrência do grande terremoto. Joaquim de Santana acusa alternadamente esta posição de ignorante e temerária, superticiosa e herética. Temerária ou mesmo herética porque se arroga a capacidade de conhecer a "verdadeira" causa do terremoto, ou conhecer o desígnio de Deus sobre os pecados dos lisboetas. Ignorante e superticiosa porque está

"bem persuadido o homem sabio, que calculou a Natureza, que todos os sobreditos, e ainda outros males são naturalissimos effeitos das suas causas Naturaes, e naturalmente reguladas."

Em última análise, aquele excerto de Malagrida é ainda "hipocrita”, "diffamador" e "insolente". Porque ao utilizar o termo "intoleráveis"

“...com elle qualifica os peccados dos moradores de Lisboa no superior gráo de graves, de publicos, e de escandalosos; e pouco 
lhe faltou para dizer, que estava Lisboa feita outra Babilonia, outra Ninive, outra Sodoma, ou alguma outra infame Cidade."

O ordenamento que Joaquim de Santana busca para a sua censura é tomado de empréstimo à tratadística, tentando mimetizar-lhe os procedimentos. Tal é particularmente claro quando o censor resume o pensamento de Malagrida através de proposições que depois contesta sistematicamente com considerandos introduzidos em latim (Primo, Secundo, Tertio etc.).

Mas na verdade o censor oscila permanentemente entre o projecto de produzir uma censura erudita e a necessidade eminentemente política de intervir na polémica sobre a execução de Malagrida e, acima de tudo, na expulsão dos jesuitas, ajudando a justificar retrospectivamente a execução do autor do Juizo da verdadeira causa do terremoto. Não é exagerado sugerir que a própria redacção da censura tenha sido encomendada de fora da Real Mesa Censória, eventualmente pelo próprio marquês de Pombal. Daí este resultado híbrido, um texto que tem forma de tratado mas conteúdo de libelo.

Destas contradições foi presa o próprio censor e nada o demonstra tão claramente como o facto de ele mesmo ter sido censurado, pois são frequentes as passagens da sua censura em que determinadas expressões foram riscadas e substituídas por outras. Conto 25 exemplos destes no documento. Logo no início, o censor chamara a Malagrida "impostor, e heresiarca": a palavra "impostor" foi rasurada. Onde, páginas mais adiante, escrevera "ignorante e famoso heresiarca Malagrida", a passagem foi alterada para apenas "Gabriel Malagrida". Noutra passagem, "o herege Malagrida" transforma-se em "o mesmo Malagrida". Noutra ainda, onde estava "diz assim o temerario, e infamador Malagrida", passou a estar "diz assim Gabriel Malagrida”. Em algumas passagens não consegue perceber-se exactamente qual o objectivo das alterações, como quando "tão malvado, aleivozo, e sacrilego" é substituido por apenas "tão aleivozo, e sacrilego".

É impossível saber exactamente o que terá acontecido. Terá sido o próprio censor a considerar supérfluas ou exageradas estas palavras, e a autocensurar-se para melhor reforçar o seu argumento? Ou terá sido a Real Mesa Censória, em plenário, a tomar essa iniciativa de censurar um seu censor, por considerar que os termos por ele empregues não eram os mais adequados?

Seja como for, nada disto tem qualquer influência na decisão final. Mas também se pode admitir que, dadas as circunstâncias políticas deste 
caso, tal decisão já houvesse sido tomada muito tempo antes, provavelmente antes mesmo de Joaquim de Santana ter dado início à sua censura:

"Procedendo pois a final, julgo, que o Papel, que tem por Titulo: 'Juizo da Verdadeira causa do Terremoto, que padeceo a Corte de Lisboa no primeiro de Novembro de 1755'. Author Gabriel Malagrida; he impio, temerario, infame, e heretico; e como tal digno das mesmas penas com que foi castigado seu Author por Herege, e inventor de novos erros hereticos: Sou de parecer, que o sobredito infame papel seja queimado publicamente na Praça do Commercio pelo Executor da Alta Justiça; e que todos os Exemplares sejam recolhidos por hum Edital, para ficarem suprimidos na Secretaria desta Meza. Lisboa 6 de Abril de 1772.”

Começámos por estas duas censuras porque elas nos ajudam, de forma muito clara, a delimitar o contexto de actuação da Real Mesa Censória. Representam cada uma delas o limiar de um outro campo, a fronteira de um território ideológico inóspito para o pombalismo. Os censores não têm contemplações quando se trata de tomar uma decisão sobre o destino de obras como estas.

Como vimos pelo conteúdo das censuras, esta condenação clara, tanto num caso como noutro, não significa de modo algum que estas duas obras sejam sobreponíveis ou que constituam para os censores ameaças qualitativamente semelhantes. Na verdade, o mundo que produziu L'an 2440 e o mundo que deu origem ao Juizo da verdadeira causa do terremoto estão nos antípodas um do outro - ou talvez, em vez de uma metáfora geográfica, cabesse aqui melhor uma metáfora temporal, visto que cada uma das obras não vem só de mundos como de tempos literalmente diferentes. Onde L'an 2440 é uma obra de ficção passada no futuro, o Juizo da verdadeira causa do terremoto reporta-se a acontecimentos reais lembrados ainda por toda a gente. Quando L'an 2440, enquanto livro estrangeiro, simboliza o perigo da decadência que vem de fora e a que o pombalismo tenta fechar as portas do reino, o Juizo..., apesar de escrito por um italiano, é uma obra imersa no contexto nacional e lisboeta, e os perigos que transporta consigo são essencialmente internos. Uma das obras pertence ao campo dos philosophes, que os censores consideram pirronista e libertino, a outra ao campo jesuitico, tido por fanaticamente devoto e supersticioso. Em termos de género e estilo nada os podia afastar mais: L'an 2440 pertence “aquellas composiçoens, que os franceses 
chamão Romans e os espanhóis Novellas... genero de obras de si mesmo... pouco conforme com a gravidade e a seriedade christãa" (12) e o Juizo herda a voz e a escrita barroca dos sermões que os deputados da Real Mesa Censória insultam com termos como "seiscentistas", "vieirianos", "implexos e pueris" ou "arcaicos" (13). Finalmente, ao passo que o Juizo da verdadeira causa do terremoto pretende ser uma memória viva do passado, L'an 2440 quer começar a constituir uma memória do futuro, uma memória prospectiva que sirva de referência e comparação às questões políticas do seu presente.

Mas apesar destes textos se encontrarem nos limites do mundo do censor, vê-se claramente pela leitura das censuras que pertencem a um território que não lhes é exterior, que não lhes é neutral nem indiferente. Os censores disputam retoricamente algum do conteúdo destas obras. A sua relação com elas é de concorrência e conflito, embora essa disputa seja diametralmente oposta em cada um dos casos: a Real Mesa Censória disputa a L'an 2440 o monopólio que os philosophes pretendem ter da razão e da natureza, ao passo que no Juizo da verdadeira causa do terremoto contesta aos jesuitas e ao campo devoto em geral o seu monopólio da devoção e da catolicidade.

A natureza destes textos é, pois, muito diversa da de outros, que embora afrontem mais claramente o núcleo de crenças dos censores, constituem um perigo menor, precisamente porque se autoexcluem do contexto em que o censor vive. Estes textos não são defesas do maometanismo ou mesmo do luteranismo. Se o fossem, estariam para além destas disputas. É que ao passo que um livro protestante pode ser admitido pela Real Mesa Censória, ainda que com condicionantes (14), com livros como L'an 2440 ou o Juizo da verdadeira causa do terremoto, que disputam as mentes dos súbditos por quem a Real Mesa Censória deve zelar, não pode haver qualquer espécie de tolerância:

"se devem prohibir mais ainda que as de Luthero ou Calvino, por serem huma Collecção de tudo o que ha de impio e blasfemo nos Autores heterodoxos mais atrevidos e mais detestaveis: e por ser a sua lição tanto mais perigoza, quanto he maior a hypocrisia, com que elle a cada passo se estâ inculcando por hum bom e irreprehensivel Filho da Igreja Catholica“ (15).

Como vimos nestas censuras, a estratégia para a conquista das áreas de fronteira em disputa traduz-se, retoricamente, em empurrar o adversário para fora da área do admissível e assim privá-lo daquilo a que os censores chamam muitas vezes "a luz pública". Estes livros tornaram-se 
“indignos da luz pública” e mesmo merecedores do fogo, porque o censor conseguiu empurrar o conteúdo deles para bem longe da fronteira em disputa e desapossá-los das virtudes de que eles se proclamavam portadores, lendo-as sob uma nova luz que as transforma definitivamente. Por artes da alquimia retórica dos censores, a "razão" e a "natureza" de L'an 2440 tornaram-se "libertinagem" e "impiedade"; a "devoção" e "religião" do Juizo da verdadeira causa do terremoto transformaram-se em "fanatismo" e "superstição".

O território de onde parte esta dupla anexação dos territórios da razão e da devoção pelos censores régios é o hinterland da soberania monárquica indisputada e inquestionável que está no centro do regalismo pombalista. Ela é não só o centro de gravidade à volta do qual gira o trabalho censório como a sua causa primeira.

Iniciámos este texto sob o signo do fogo: o fogo que consumiu as páginas de L'an 2440, o fogo com que foi "queimado publicamente na Praça do Commercio" o Juizo da verdadeira causa do terremoto, o fogo que vitimou Gabriel Malagrida. No entanto, devo confessar que não considero este o melhor signo sob o qual colocar uma descrição da censura no Antigo Regime - apesar de ter sido exactamente isso o que fiz. O fogo é um lugar-comum de tal forma associado à censura de livros que chega a constituir, um pouco à maneira heráldica, o seu emblema. Mas o fogo atrai demasiado a nossa atenção para os resultados da censura e distrai-nos da censura enquanto processo. Isto tem feito das censuras documentos um tanto menosprezados.

Dada a história recente da censura, o senso comum tem tendência a ver as censuras como uma espécie de "não-objecto". A censura limita-se a ser os cortes realizados na obra de outrem, ou os exemplares de um livro queimado, ou a listagem dos livros proibidos num Index. Dir-se-ia que a censura se assemelha a um buraco negro, de que só nos damos conta pela energia que consome, sem produzir nada de palpável. No entanto, e sem negar que a razão de ser da censura é por definição eminentemente repressiva, exige-se um certo esforço contra-intuitivo para passar a considerar as censuras enquanto objectos - recorde-se como, do ponto de vista puramente repressivo, a censura ao Juizo da verdadeira causa do terremoto parecia redundante. Vimos anteriormente como as censuras são textos que se relacionam e dialogam com outros textos e que, por vezes, são muito ricos em informação sobre a forma como são escritos, lidos e interpretados no seu contexto. 
O fogo é ainda, no que diz respeito à Real Mesa Censória, duplamente inadequado por outra razão mais prosaica, que é a de que foi pouco utilizado enquanto instrumento repressivo por esta instituição. Na verdade, nos nove anos de produção documental sobre que aqui nos debruçamos - os nove anos que, recordemo-lo, medeiam entre a fundação da Real Mesa Censória em maio de 1768 e a exoneração do marquês de Pombal em 1777 - estão apenas registrados seis casos de livros mandados queimar pela instituição. Entre eles casos contam-se, para além de L'an 2440 e do Juizo da verdadeira causa do terremoto, obras de Helvetius e um texto anónimo, Sur la destruction des jesuites en France (note-se como as poucas outras censuras que levaram à queima pública dos livros seguem as mesmas linhas de fractura que as duas primeiras analisadas).

Podemos colocar este facto em contexto, fornecendo alguns breves dados estatísticos. Entre 1768 e 1777 foram censurados - ou seja, examinados (16) - pelos deputados da Real Mesa Censória cerca de um milhar e meio de textos. Destes, foi concedida licença a mais de metade (774 textos, $53,34 \%$ ), ao passo que pouco mais de um terço foi suprimido $(35,29 \%, 512$ textos $)$. Os censores alteraram ainda quase um décimo deles $(9,58 \%, 139$ textos), rasurando passagens ou modificando-os. É um desses exemplos que nos interessará nos próximos parágrafos.

Trata-se, de novo, de uma censura de Joaquim de Santana, desta vez a uma tradução do Discurso sobre a História Universal para explicar a continuação da religião, e as mudanças dos Imperios, "original Francez, composto pelo Bispo de Meaux Jacob Benigno Bossuet” (17).

Bossuet era um autor estimado pelos censores pombalinos e o mercado editorial sabia-o bem, pelo que o número de traduções deste autor aumentou de forma constante durante a autoridade da Real Mesa Censória sob o consulado pombalino. À vista do regalismo pombalista Bossuet era um autor consagrado. $\mathrm{O}$ censor começa aliás por o deixar claro: a obra em apreço "tem o distinto merecimento, que tem todas as outras composições do sobredito Prelado". Trata-se, pois, de um caso relativamente corrente, sem o grau de tensão ou animosidade que atravessava os exemplos anteriores - ou antes, um caso relativamente. Este facto faz dele um bom exemplo do trabalho comum do censor da Real Mesa Censória, uma espécie de mediana da censura pombalina que utilizaremos para contrapor aos seus extremos com que já nos ocupámos. 
Não quero com isto dizer que seja um texto menos revelador do que os anteriores. Na verdade, e apesar de ser uma censura curta, trata-se de um belíssimo exemplo que reúne em si vários aspectos do trabalho do censor. Sendo Bossuet um autor quase aprovado a priori, o censor baixa a guarda e, ao contrário do que tinha acontecido na censura a Malagrida, deixa escapar alguns impensados muito significativos sobre o seu próprio trabalho, sobre a obra que lê, a posição da instituição de que faz parte e o contexto do público para que trabalha. $\mathrm{Na}$ impossibilidade de explorar de forma satisfatória todos estes aspectos, opto nos parágrafos seguintes por citar na íntegra o texto, alinhando em seguida algumas pistas de análise que me parecem sobressair dele.

"O Livro intitulado, = Discurso sobre a Historia Universal para explicar a continuação da Religião, e as mudanças dos Imperios $=$, he huma traducção do original Francez, composto pelo Bispo de Meaux Jacob Benigno Bossuet.

Nesta obra, que seo Author dividio em Epocas, se deixão ler como em resumo, e compendio os principaes, e mais famosos accontecimentos da Historia da Igreja, e dos Imperios. He esta a primeira parte, e tem o distinto merecimento, que tem todas as outras composições do sobredito Prelado.

Persuadime contudo, que era digno da nossa reflexão, o que Bossuet escreveo, fallando de Childerico III. Rey de França. He o seguinte.

'Childerico, o mais miseravel de todos os Principes, lhe abrio o caminho, e ajuntou à qualidade de negligente a de insensato. Os Francezes disgotados das suas negligencias, e acostumados desde tanto tempo à caza de Carlos Martel, fecunda em grandes Homens, não vivião embaraçados mais que pelo juramento, que havião dado a Childerico. Á vista da resposta do Papa Zacharias se julgarão livres, e tanto mais desobrigados, que havião dado ao seo rey, que \&c.'

Este livro pela estampa da-se a ler a todos os Portuguezes, huns mais, outros menos instruidos, e outros totalmente idiotas, e ignorantes, e lendo alguns dos sobreditos a referida passagem, certamente se persuadirão, que o Papa está munido de poder legitimo para relaxar os juramentos de fidelidade, e obediencia que os vassalos dão a seos Principes, Reys e Senhores, fazendolhe pezo assim o haver entendido uma Nação tão illuminada como a Franceza, sem reflectirem que o não era naquelle seculo; e pode 
ser chamem a si a authoridade de hum Escritor tão insigne como Bossuet, que assim (dirão eles) o entendeo, pois não duvidou escrever o sobredito facto no seo Discurso à Historia universal.

Esta Meza, que incansavelmente vigia sobre a boa instrucção dos Portuguezes, deve tirarlhe tudo, que pode ser occasião de falsas, e perniciozas preocupações, como he a sobredita, e outras similhantes. Não se devendo pois mutilar a obra, nem encobrir hum facto historico, devese uzar de hum remedio facil, e prudente. Ilustrou o Traductor a sobredita obra com algumas Notas, que elle mesmo diz serem suas; he pois o meu parecer, que se lhe mande accrescentar mais huma à sobredita passagem, em que o diga, que tal era a preoccupação das gentes naquele seculo de ignorancia, persuadindo-se alguns erradamente que o Pontifice Romano tinha poder de relaxar o juramento de fidelidade e obediencia, que os vassalos dão aos seos Reys, Principes, e Senhores.

Devo tambem dizer, que esta Traducção está escrita com aquella orthografia, que reprehendem os homens serios, e instruidos; suprimindo a letra h nas palavras homem, Historia, hora, huma; não pondo letra grande depois do ponto, e outros usos similhantes a estes, os quaes não pode por em estabelecimento hum, ou outro particular contra o commum de huma Nação inteira. Esta Mesa tem proposto o dileberarse [sic] sobre este assumpto, e persuadome, que se não deve deixar imprimir esta obra com a sobredita orthografia antes da ultima deliberação. Sou pois de parecer, que se mande ao Traductor emendar a orthografia. Forão do mesmo parecer os Deputados adjuntos. Lxa. 18 de Fevereiro de 1771."

Gostaria pois de salientar os seguintes pontos, por ordem de aparecimento no texto:

- Em primeiro lugar, o tom casual com que o censor faz o elogio ao autor, e que dá a medida da incontrovérsia da obra deste. Enquanto teorizador central do absolutismo francês, o censor admite que Bossuet está aprovado à partida (“...o distinto merecimento, que tem todas as outras composições do sobredito Prelado”).

- Contudo, dir-se-ia que nem com o absolutista mais clássico pode o regalismo pombalista estar descansado, o que leva o censor a destacar um excerto "digno da reflexão" da Real Mesa Censória. 
- Nota-se em seguida como o censor tem uma consciência clara do nexo entre mensagem e meio, chamando a atenção para o poder da imprensa ("Este livro pela estampa da-se a ler a todos os Portuguezes...”). Pode especular-se sobre se o censor teria achado necessário intervir na obra caso não tivesse em mãos uma tradução para ser impressa no reino, mas uma importação do original francês, acessível a menos gente por razões técnicas, comerciais e linguísticas.

- Torna-se depois claro não ser exactamente o texto nem o autor que estão em causa, mas as possíveis interpretações de ambos. O censor, nitidamente, preocupa-se em prevenir a imprevisibilidade das leituras do público (da mesma forma como, aliás, os autores se procuram precaver, através da auto-censura ou da dissimulatio, contra a imprevisibilidade das leituras dos censores) e sabe que ao chegar à "luz pública" o texto está sujeito a uma grande diversidade de leitores possíveis dentro do público. Pratica mesmo uma rudimentar sociologia da leitura ("huns mais, outros menos instruidos, e outros totalmente idiotas, e ignorantes”).

- A censura é um diálogo que por vezes se assemelha a um jogo de xadrez: a presciência do censor a respeito das leituras possíveis do texto chega ao ponto de incluir ainda a previsão das possíveis apropriações do texto por parte dos leitores, e a antecipação política das possíveis utilizações retóricas da passagem citada por parte dos leitores ("pode ser chamem a si a authoridade de hum Escritor tão insigne como Bossuet...").

- É também interessante ver como o censor decide intervir através das notas do tradutor nas possíveis interpretações dos leitores, tentando assim estabelecer previamente a grelha de leitura canónica para a passagem de Bossuet em apreço.

- Ainda a respeito deste ponto, note-se como o censor respeita a canonicidade do autor, evitando por todos os meios que se possa "mutilar a obra", o que obviamente não aconteceria se o autor fosse outro.

- Por último, a interessante emergência de uma preocupação com a ortografia do texto, uma preocupação que ocorre repetidamente na documentação da Real Mesa Censória. Trata-se de uma questão complexa e cheia de peripécias mesmo dentro do interior da própria Real Mesa Censória, e que chegou a provocar polémicas entre os censores, que explorei já noutro local (18). Quereria notar ape- 
nas duas expressões do voluntarismo cultural do pombalismo, de nítido recorte homogeneizador (“...outros usos similhantes a estes, os quaes não pode por em estabelecimento hum, ou outro particular contra o commum de huma Nação inteira"), e no qual a Real Mesa Censória tem um papel central, pois é a ela que lhe compete deliberar sobre a ortografia legal a utilizar nas obras impressas no país.

Em resumo, a censura constitui, para nós, uma porta de entrada privilegiada no mundo da recepção dos textos, porque constitui ela própria uma reflexão sobre a leitura, o mercado editorial, a escrita e o debate intelectual. Poder-se-á objectar que ela o faz a partir de um ponto de vista demasiado tipificado e que detem uma visão distorcida da realidade. Será possível. Mas não se pode discutir que é também um ponto de vista privilegiado sobre esta realidade.

"Quemar libros y erigir fortificaciones es tarea común de los príncipes” (19), escreve Jorge Luís Borges num seu conto no qual especula sobre a figura de Shih Huang Ti, o imperador chinês que mandou edificar a grande muralha da China - e mandou também queimar todos os livros produzidos antes dele. Segundo Borges, estas duas medidas são as duas faces de uma mesma moeda: com a muralha o imperador desejou delimitar o espaço e com a queima dos livros quis delimitar o tempo e obrigar a "que la historia empezara con él". Segundo Borges, ambas as medidas são o reflexo de um desejo de imortalidade inerente ao exercício do poder. O imperador sonhara fundar uma dinastia imortal: “ordenó que sus herederos se llamaran Segundo Emperador, Tercer Emperador, Cuarto Emperador, y así hasta lo infinito...”.

Este conto relembra-nos, se tal necessidade existe, que o poder se exerce sempre por oposição a outro espaço e a outro tempo. A "abolição do passado" de Shih Huang Ti é apenas uma manifestação grandiosa (à altura da grandiosidade da muralha), desta dupla oposição. No entanto, tal como a muralha é um trabalho imperfeito, também esta abolição do passado é impossível. Se sabemos que houve uma fogueira de livros é porque houve livros antes; só a memória do passado e não o próprio passado se pode sujeitar à intervenção.

Ainda assim, essa intervenção sobre a memória é crucial para a prática do poder. A censura, tal como a propaganda, desempenharia assim, 
no território da memória, o equivalente às funções que desempenham as fortalezas, os baluartes e os exércitos no território real, geográfico, dos reinos e dos impérios.

Nas três censuras da Real Mesa Censória que considerámos até agora encontramos essa função expressa de maneira clara, nomeadamente nos casos em que o conteúdo dos textos repugna à visão regalista da soberania monárquica. Em L'an 2440, o censor insurge-se contra a visão que o autor apresenta de Richelieu - lembrando afinal que aquele livro, apesar de futurista, é tanto uma memória do passado como do futuro.

No caso de Bossuet, o censor só não elimina a passagem em que o Papa desobriga os súbditos franceses do juramento de fidelidade ao seu rei porque se tratava de um livro de Bossuet; no entanto, obriga o tradutor a incluir uma nota caracterizando aquela época como um "seculo de ignorancia" - o passado foi de facto assim, mas apenas porque se equivocou. A verdade é que nem sequer no mundo do passado um papa pode desobrigar os súbditos do juramento de fidelidade que estes fizeram ao seu rei.

No caso de Malagrida a disputa pela memória é ainda mais clara, evidentemente porque se trata da memória dos portugueses e de uma memória mais recente, bem mais próxima das linhas de delimitação do pombalismo, no próprio interior do reinado de D. José I. Malagrida defende que o sismo foi causado pelos pecados dos lisboetas naqueles tempos? O censor contra-ataca, intervindo sobre a memória desse passado anterior ao grande sismo, mas acima de tudo, do passado anterior ao pombalismo. Este não é referido, mas está implícito:

“Confrontemos Lisboa comsigo mesma; vejamos o como esta Capital se conduzia pelo anno de 1755 e o como se condusira annos antes do Terremoto do primeiro de Novembro. Muitos sabem que naquelles tempos anteriores esteve a justiça em muitos, dos que a administravam, bastantemente corrumpida: Que os Templos do Senhor eram casas de abominação, e escandalo; ali se ouviam as conversações impudicas, e se viam os acenos escandalosos, as acções lascivas, a entrega dos bilhetes amatorios, e outras cousas, torpes, e peccaminosas, sendo taes, e determinadas Igrejas as mais celebradas, por serem theatros mais famosos dos sobreditos escandalos.

Que as tardes dos Domingos da Quaresma, que por ser tempo designado pela Igreja para a penitencia, se fazia mais recommendavel a modestia, a decencia, e a santidade, eram, as que a malicia 
reputava mais opportunas para as sobreditas dissoluções, e desacatos; pois eram publicos, e a todos notorios os que se faziam assim dentro dos Templos, como fóra delles nos seus atrios. Que os Mosteiros das Esposas de Jesus Christo eram continuas assembleas de conversações sacrilegas; vendo-se sempre as portarias, e locutorios occupados de homens de todos os estados, que faziam publico capricho de sua dissolução; comunicando huns aos outros suas illicitas, e escandalosas correspondencias.

Que o Pateo das Comedias era a perdição das casas, e ruina das consciencias da Nobresa desta Corte. Finalmente que os concubinatos eram tão publicos, que quasi se tinha perdido, não digo ja o Santo Temor de Deos, porem o mesmo pejo natural; havendo Cavalheiros, que davam publica conversação aos seus iguaes nas proprias casas de suas Damas. E devêra notar o Malagrida, que naquelles annos em que isto sucedeo a vista e face desta Corte, não houve terremotos.

He bem certo, que muito annos antes de 1755 não só não existiram os sobreditos escandalos; mas que a elles haviam succedido a sezudesa, a emenda dos costumes, e até devoção universal de toda esta Corte. Sim haviam peccados, porque não deixará de os haver, em quanto houver mundo, habitado por homens de huma natureza debil, frouxa, e corrumpida com hum peccado de origem, que passa de huns, a outros como herança fatal; porem não havia alguns dos referidos escandalos."

Mais uma vez, o pombalismo dialoga, pela voz de um deputado da Real Mesa Censória, com o seu passado. Tal como com Shih Huang Ti, dir-se-ia que ele o assombra. Não se trata de uma novidade: a censura (bem como a propaganda) é uma forma de intervir sobre as memórias do passado e de reconfigurar as narrativas através das quais ela sobrevive.

Na sua célebre obra sobre cultura e imperialismo, Edward Said nota que "[o] poder de narrar, ou de bloquear a formação e emergência de outras narrativas, é muito importante tanto para a cultura como para o imperialismo, e constitui uma das principais ligações entre ambos” (20). Julgo que, tendo em conta as passagens citadas, poderíamos sem objecções ampliar o raciocínio, transpondo-o para uma fórmula como: “o poder de narrar, ou de bloquear a formação e emergência de outras narrativas, é muito importante tanto para a memória como para a censura e constitui uma das principais ligações entre ambas”. De facto, não são apenas os regimes colonialistas a que Said se refere no seu estudo que se relacionam desta forma vital com as narrativas; qualquer poder busca a sua 
legitimação nas narrativas. Qualquer poder, regime ou instituição se funda, literalmente, com uma narrativa e se justifica através da narrativa também. Como o próprio Said nota ainda, "nations themselves are narrations" (21).

O voluntarismo pombalista não possuiu a escala do de Shih Huang Ti. Constituiu contudo um momento poderoso de reconfiguração da memória colectiva, sem par em qualquer outro do século XVIII português, e um dos mais radicais da Europa pré-revolucionária. E a instituição da Real Mesa Censória, bem como a reforma da Universidade de Coimbra na mesma época, foram algumas das formas principais de delimitação do passado que o regime utilizou.

O pombalismo viveu claramente ancorado na criação e rememoração de narrativas que lhe eram muito próprias ou mesmo exclusivas. Pode dizer-se que grande parte do poder acumulado pelo marquês de Pombal se fundou na forma como impôs as suas narrativas (sobre a expulsão dos jesuitas e sobre o atentado ao rei, nomeadamente), às vezes à custa (como vimos no caso de Malagrida) da inflacção de factos aparentemente banais. Por isso seria satirizado, após a sua queda, por ser um "amplificador de nadas", além de um "inimitável criador de palavras gigantescas" - caracterização onde está presente a dupla vertente de reformismo cultural e controle da memória que presidiu a medidas como a instituição da Real Mesa Censória.

"A memória", diz Pascal num dos seus Pensamentos, que serve como epígrafe a este artigo, "é necessária a todas as operações da razão". Enquanto inventor da primeira máquina capaz de realizar cálculos "sans aucun travail d'esprit" (22) e precursor do que hoje se chama inteligência artificial, Pascal teria necessariamente uma noção aguda de como a razão humana se funda na memória - ou de como não existe inteligência sem memória.

A segunda epígrafe escolhida para este texto fornece um contraponto a esta realidade. É retirada de outro célebre conto de Jorge Luis Borges (23). O seu protagonista, Ireneo Funes, é um homem - já de si de prodigiosa memória - que após um acidente perde de todo a capacidade de esquecer:

“Ahora su percepción y su memoria eran infalibles... sabia la forma de las nubes australes del amanecer del treinta de abril de mil 
ochocientos ochenta y dos y podía compararlas en el recuerdo con las vetas de un libro en pasta española que sólo habia mirado una vez y con las líneas de la espuma que un remo levantó en el Río Negro la víspera de la acción del Quebracho... Podía reconstruir todos los sueños, todos los entresueños. Dos o tres veces había reconstruido un dia entero; no había dudado nunca, pero cada reconstrucción había requerido un día entero.”

Ireneo Funes vivia num estado letárgico, não só porque após o seu acidente ficara paralisado, mas também porque, tolhido pela sua memória absoluta, não era capaz de verdadeiramente tomar decisões. Por isso desconfia o narrador que Ireneo Funes não era, no fundo, capaz de pensar, pois para pensar há que "esquecer diferenças, generalizar, abstrair" (24).

Queria defender aqui que o que vale para a razão humana vale para a razão de estado: sem memória não existe; sem esquecimento não sobrevive. Não no surpreendamos pois se, numa época como o pombalismo - em que funda de forma decisiva a razão de estado em Portugal (25) -, existe este esforço tão vigoroso para controlar não só o que se lembra e a forma como se lembra, como também o que se esquece e a forma como se esquece.

O pombalismo é celebre por este esforço por vezes paradoxal. No caso da narrativa do atentado ao rei, por exemplo, são conhecidos os esforços para perpetuar na memória colectiva a execução dos Távora mandando imprimir folhetos em que ela é cruelmente recontada em todos os seus pormenores -, ao mesmo tempo que os seus nomes são apagados de lápides e inscrições. Não se tratava, pois, de banir totalmente a memória dos Távora, mas de a reformular - garantir que eles fossem lembrados e esquecidos apenas de determinada forma. No caso da narrativa anti-jesuítica são também conhecidos inúmeros exemplos de reformulação da memória, nomeadamente com a produção do monumento acusatório que é a Deducção chronológica (de 1768, o ano da fundação da Real Mesa Censória) e que é, ao mesmo tempo, uma releitura geral da história do reino. O caso de Gabriel Malagrida e a censura aqui citada fazem parte dessa releitura.

Estas "delimitações do passado" cumprem uma função repressiva ao serviço de um imaginário reformista. Não é por acaso que o início da reforma da Universidade de Coimbra é desde logo marcado pela decisão política de escrever um Compêndio histórico (26) da instituição (e denúncia da acção dos jesuitas), projecto cuidadosamente acompanhado pelo próprio Pombal e que congregou os esforços de diversos membros da 
elite cultural pombalista - entre eles os do presidente da Real Mesa Censória, frei Manuel do Cenáculo, um autor erudito e bibliófilo, bispo de Beja e arcebispo de Évora, fundador da Biblioteca de Évora e um dos vultos mais importantes do iluminismo português (27). A interpretação do gesto é clara: uma reforma deve iniciar-se e justificar-se através de uma releitura do passado.
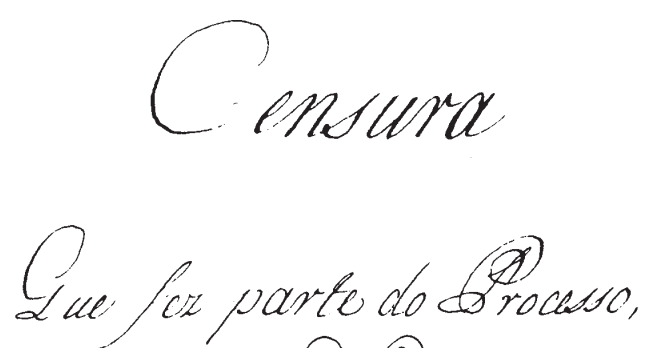

sets quat for conderiaco a peraide

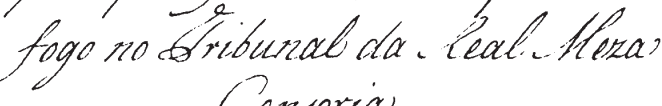

Cersoria)

(bapeli intitulado

Q fuis da verdadeiro causa. do berremoto

que padeceo a Corke de wboa, prisuesto de fócestutro de 1955
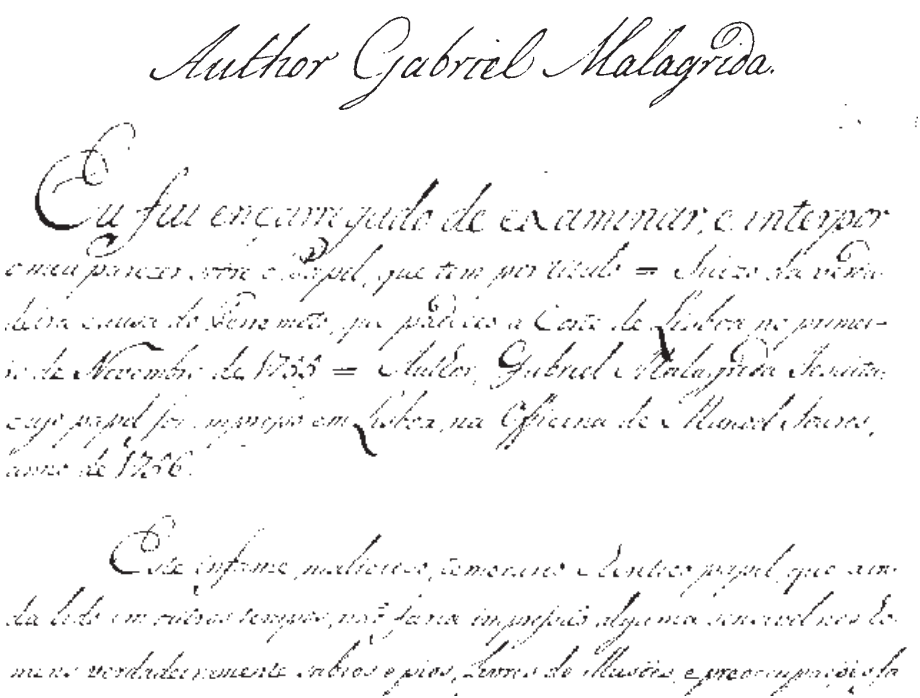

Manuscrito da censura de Joaquim de Santana ao livro Juizo da Verdadeira Causa do Terremoto, de Gabriel Malagrida (1772) 
Este carácter aparentemente contraditório da relação do pombalismo com a cultura marca na sua essência a fundação da Real Mesa Censória, uma instituição repressiva entendida pelos próprios censores como um garante do avanço das letras e das luzes no reino. Recorde-se a autorepresentação de Joaquim de Santana na sua censura a Bossuet:

"Esta Meza, que incansavelmente vigia sobre a boa instrucção dos Portuguezes...".

Elemento central na política cultural do pombalismo, a Real Mesa Censória é pouco conhecida e estudada. A historiografia clássica dividiu-se sobre o tema e mesmo na literatura mais recente a natureza da sua acção é confusa. Foi provavelmente pensando nestas contradições que o satirista anónimo já citado chamou a Pombal um "restaurador quimérico das letras", mas um "real perseguidor dos sábios". E foi certamente pensando em questões como a Real Mesa Censória e como ela não se encaixa bem no nexo que o senso comum estabelece entre iluminismo, tolerância, pluralismo e abolição da censura que Kenneth Maxwell chamou a Pombal um "paradoxo do iluminismo".

Para fechar o círculo, gostaria de regressar à censura com que iniciámos este artigo.

O leitor recordar-se-á provavelmente que Lobo da Cunha não sabia o nome do autor de L'an 2440. Trabalhando com uma edição clandestina e anónima, as hipóteses de que soubesse quem era o autor do livro que examinava eram mínimas. Esse autor chamava-se Louis-Sébastien Mércier e o título completo da sua obra era L'an deux mille quatre cents quarante, rêve s'il en fût jamais.

A figura e a obra deste autor só começaram a ser recuperadas e valorizadas recentemente, nomeadamente através do trabalho de Roger Chartier e Robert Darnton (28). Esta desatenção pode justificar-se em parte na medida em que Mércier é um autor menor na França do século XVIII. LouisSébastien Mércier volta a interessar, hoje, aos estudiosos não só pela forma como tentou emular os seus contemporâneos maiores (Voltaire e Diderot, mas muito especialmente Rousseau), mas também pelo facto muito mais prosaico que vendeu mais exemplares do que qualquer um deles.

Na verdade, L'an 2440 parece ter vendido mais - a acreditar nas fontes disponíveis (29) - do que qualquer outro livro durante o século 
XVIII. Proibido em França pelos censores da Direction de la Librairie ou então, prevendo uma mais que provável condenação, directamente enviado para o circuito paralelo - foi editado pela primeira vez em Amesterdã no ano de 1771 e reeditado diversas vezes nos anos seguintes em cidades fora de França - ou, possivelmente, em edições contrafeitas no interior de França com falsas indicações de proveniência. A edição que chegou às mãos da Real Mesa Censória fora impressa em Londres.

Além de ter sido o melhor exemplo de best-seller e portanto servir como um inestimável barómetro do gosto literário e do consumo livreiro da época, de ser uma síntese de sucesso das ideias filosóficas heterodoxas dos autores-chave do iluminismo francês e de ser ainda um caso fundamental para o estudo de como a literatura clandestina preparou (ou não) o caminho da Revolução Francesa - o que constitui uma das principais linhas de investigação de Darnton - , L'an 2440 interessa-nos ainda por outras razões.

Como vimos no início deste artigo, não poderiam ser mais distantes as posições de L'an 2440 das dos censores portugueses. António de Santa Marta Lobo da Cunha e Louis-Sébastien Mércier estavam, se assim nos podemos exprimir, em opostas extremidades da barricada. No entanto...

No entanto, existe uma comunidade muito grande entre a Real Mesa e o livro futurista de Mércier, e logo no aspecto que mais nos interessa no decurso deste trabalho: a relação com os livros e com as memórias que eles transportam. Tal como o pombalismo, o mundo reformado do século XXV que Mércier imagina tem uma relação conflitual com as narrativas que transportam as memórias do passado e trabalha para as reconfigurar a bem da iluminação dos seus cidadãos. Mais uma vez, o fogo, se bem que não definindo essa relação, se impõe como a imagem que os próprios contemporâneos criam dela.

Ao observar a visita que o narrador de L'an 2440 faz à Biblioteca do Rei (um capítulo que, curiosamente, o censor cita na sua censura, mas sem aprofundar nem referir o seguinte episódio) poderíamos mesmo formular a questão: foi Pombal que foi um paradoxo do Iluminismo, ou terá sido próprio Iluminismo e a sua relação com a memória paradoxal por si mesma?

“O que ocorreu às vastas quantidades de livros impressos que já no século XVIII se acumulavam na biblioteca real? perguntou. Queimámolos, respondeu o bibliotecário: 800000 volumes de leis, 50000 dicioná- 
rios, 100000 obras de poesia, 1600000 livros de viagens, e 1000000000 de romances desapareceram todos num gigantesco auto-de-fé. Quer isso dizer que o regime de 2440 é hostil à palavra impressa? De todo: a imprensa provou ser a mais importante força da história, e os franceses protegem a sua liberdade mantendo a imprensa inteiramente livre. Não queimaram os livros porque os desprezassem mas porque temiam o seu poder. A maior parte da literatura passada envenenava o corpo político ao lisonjear os grandes e cultivar gostos corruptos. Uma comissão de virtuosos letrados filtrou então todos os sãos ingredientes de tudo o que fora impresso nos séculos passados e destilou-os até à sua essência, que coube facilmente num pequeno volume em duodécimo" (30).

Notas

1 Pascal, Euvres Complètes, Paris, Seuil, 1998.

2 Jorge Luis Borges, Obras completas, v. 1, Barcelona, Emecé, 1989, p. 485490.

3 Lisboa, Arquivos Nacionais Torre do Tombo (a partir daqui, apenas ANTT), Real Mesa Censória, caixa 10, 1777, doc. 5. De notar que todos os itálicos usados nas citações, bem como outras convenções (o sinal "=" para indicar citação, por exemplo) são as empregues pelos próprios censores. Utilizarei a partir daqui, por uma questão de facilidade, a designação alternativa, também utilizada pelo censor, de L'an 2440.

4 ANTT, Real Mesa Censória, caixa 8, 1772, doc. 18a.

5 Em Psalm., 147 (referência do censor).

6 Mais tarde, o censor examinaria também o livro, mas apenas para verificar se não tinha sido introduzido texto adicional ao manuscrito que fora censurado. Essa segunda fase do trabalho era mais automática e a conclusão mais sumária: "visto estar conforme com o original, pode correr" (que era a declaração com que até 1768 costumava finalizar-se a secção das censuras impressas no próprio livro, precedendo a obra que tinha sido aprovada). No entanto, esta fase do trabalho, meramente fiscalizadora, já pouco tem a ver com a censura, entendida na altura, como exploraremos mais à frente, como uma leitura aprofundada e crítica de um texto.

7 Infelizmente, a história do caso Malagrida (para não falar do contexto mais vasto da polémica jesuítica) é demasiado longa para ser tratada aqui. Limitemonos a assinalar o facto de que, no ano de 1772 , a polémica em torno da execução de Malagrida se encontrava longe de estar esgotada. A título de 
exemplo, refira-se uma obra em italiano, editada em 1784 [ Il buon raziocinio sul famoso Processo, e tragico fine del fu P. Gabriele Malagrida fatto morire a Lisbona..., Lugano], em que ela é contestada, e em que, curiosamente, se argumenta contra a censura de Joaquim de Santana. Esta terá, portanto, circulado manuscrita e clandestina, embora seja impossível saber até que ponto terá sido esta circulação premeditada pela própria Real Mesa Censória (o que evidentemente contribuiria também para explicar o cuidado posto na sua elaboração). Que os autores de Il buon raziocinio leram a censura de Joaquim de Santana não pode haver dúvida, dado que a citam: "Accusato quest'Opusculo dopo molti anni alla Mensa Censoria, non ostante essere uscito nel 1756 con tutte le licenze, ed approvazioni, vale a dire del Re, del Patriarca, e dell'Inquisizione (non ancora lacera, nè tiranneggiata, come la fu dipoi, dal prepotente Ministro Carvaglio) venne immediatamente condamnato; colla censura di essre 'scritto con ispirito infame, fanatico, malizioso, temerario, ed eretico'. E tutto ciò, perchè attribuavasi in esso dall'Autore il flagelo sofferto a gastigo di Dio, per li pubblici peccati, che comettevansi tuttodi in detta cittá di Lisbona" (Op. cit., $\$$ XIII).

8 Cf. Gabriel Malagrida, Juizo da verdadeira causa do terremoto que padeceo a corte de Lisboa, no primeiro de novembro de 1755, Lisboa, Oficina de Manoel Soares, 1756.

9 ANTT, Real Mesa Censória, caixa 8, 1772, doc. 18a.

10 Trata-se da censura ao livro de Malagrida por António Duarte da Silva, um desembargador e juiz do Tribunal da Legacia que examinara o livro em nome do "ordinário", ou seja, a censura episcopal. Cf. Gabriel Malagrida, op. cit., p. 33-34.

11 Malagrida, op. cit., p. 3-4.

12 A citação pertence a uma outra censura, realizada por António Pereira de Figueiredo a uma obra de la Chapelle, Les amours de Tibulle. Cf. ANTT, Real Mesa Censória, caixa 4, 1768, doc. 49.

13 São inúmeros os casos em que se utilizam expressões deste género. A título de exemplo, cf. a censura de António Pereira de Figueiredo a um Supplemento ao systema retorico, de João Rodrigues (ANTT, Real Mesa Censória, cx. 6, 1770, doc. 5); ou a censura de Matias da Conceição a uns Dialogos sobre a rethorica christã, ou Arte de bem pregar a palavra de Deus, de Manuel de Santana (ANTT, Real Mesa Censória, cx. 9, 1776, doc. 53).

14 Existem alguns casos, de que o mais interessante é a censura de João Baptista de São Caetano às Centúrias de Magdeburgo (ANTT, Real Mesa Censória, cx. 6, 1770, doc. 92), não esquecendo as obras dos juristas protestantes, como Grócio ou Puffendorf, que são alvo de constantes elogios por parte dos censores pombalinos. 
15 ANTT, Real Mesa Censória, caixa 4, 1768, doc. 123. Trata-se do final de uma censura de António Pereira de Figueiredo a uma Collection complete des oeuvres de mr. de Voltaire.

16 O termo "censurar" não tinha, à altura, o significado fixo que veio adquirindo nos últimos séculos. Para os censores da Real Mesa Censória e os seus coevos, a palavra tinha uma amplitude semântica maior, sendo talvez identificada maioritariamente com "examinar", ou "criticar". A frase "um livro censurado", que para um ouvinte actual evocará de forma quase unívoca, um livro "proibido" ou "expurgado" significaria então "um livro examinado" ou apenas "um livro que passou pelas mãos de um censor". Cf. Rafael Bluteau, Vocabulario portuguez e latino, Coimbra, Collegio das Artes da Companhia de Jesus, 1712-1728, entradas "Censor" e "Censura".

17 ANTT, Real Mesa Censória, cx. 7, 1771, doc. 13.

18 Ver, a este propósito, a minha tese, O labirinto censório. A Real Mesa Censória sob Pombal, p. 144-149.

19 Jorge Luís Borges, La muralla y los libros, em Otras inquisiciones (Cf. Obras completas, Barcelona, Emecé, 1989, v. II, p. 11-13).

20 Edward Said, Culture and Imperialism, p. xiii (tradução minha; no original: "The power to narrate, or to block other narratives from forming and emerging, is very important to culture and imperialism, and constitutes one of the main connections between them").

21 Id., p. Xiii. Itálico do autor.

22 Blaise Pascal, Lettre dédicatoire a monseigneur le chancelier sur le sujet de la machine d'arythmétique (1645). Cf. CEuvres complètes, Paris, Seuil, 1998, p. 187-191.

23 Jorge Luis Borges, Funes el memorioso, em Ficciones (Obras completas, v. 1, Barcelona, Emecé, 1989, p. 485-490).

$24 I d .$, p. 490.

25 Cf. Hespanha \& Xavier, A representação da sociedade e do poder, p. 137-141. Cf. também Silva Dias, Pombalismo e teoria politica.

26 Compendio historico do estado da Universidade de Coimbra no tempo da invasao dos denominados Jesuitas e dos estragos feitos nas sciencias..., Lisboa, Regia Off. Typ., 1772.

27 Cf., a este propósito, Marie-Hélène Piwnik, Echanges erudits dans la Péninsule Ibérique (1750-1767), Paris, Fundação Calouste Gulbenkian, 1987.

28 Robert Darnton estuda esta obra no seu livro The forbidden best-sellers of pre- 
revolutionary France, onde apresenta também uma versão resumida do texto original, cujos comentários e tradução para inglês seguiremos nestas páginas, na falta de uma versão francesa.

29 Encomendas de livreiros, catálogos de bibliotecas ocasionais e, acima de tudo o arquivo da Société Typographique de Neuchâtel. Cf. nota anterior.

30 Robert Darnton, The Forbidden Best-Sellers of Pre-Revolutionary France, p. 133-134 e uma versão traduzida para inglês p. 300-336. Tradução minha.

Referências bibliográficas

BAUMAN, Zygmunt. Legislators and interpreters. Cambridge, Polity, 1987.

BOUZA, Fernando. Para no olvidar y para hacerlo. La conservación de la memoria a comienzos de la edad moderna. In: Imagen y propaganda. Capitulos de historia cultural del reinado de Felipe II. Madrid, Akal, 1998, p. 26-57.

CARDIM, Pedro (org.). A História: entre memória e invenção. Lisboa, CNCDP/Europa-América, 1998.

DARNTON, Robert. Censorship, a comparative view: France, 1789 - East Germany, 1989. Representations, n. 49, p. 40.

The forbidden best-sellers of pre-revolutionary France. Nova Iorque, WW Norton, 1996.

DIAS, J.S. da Silva. Pombalismo e teoria-política. In: Cultura - História e Filosofia, v. 1. Lisboa, INIC, p. 45-114.

HESPANHA, António Manuel \& XAVIER, Ângela Barreto. A representação da sociedade e do poder. In: MATTOSO, José (dir.), HESPANHA, Antonio Manuel (coord.). História de Portugal, v. 4: O antigo regime. Lisboa, Círculo de Leitores, 1993.

JANSEN, Sue. Curry, Censorship - The knot that binds power and knowledge. Oxford, Oxford University Press, 1991.

MAXWELL, Kenneth. Pombal - Paradox of the enlightenment. Cambridge, Cambridge University Press, 1995.

PATTERSON, Annabel. Censorship and interpretation - The conditions of writing and reading in early modern England. Madison, The University of Winsconsin Press, 1984.

SAID, Edward. Culture and imperialism. Londres, Vintage, 1993.

TAVARES, Rui. O labirinto censório. A Real Mesa Censória sob Pombal (1768- 
1777). Lisboa, 1998. Tese (mestrado). Instituto de Ciências Sociais da Universidade de Lisboa.

RESUMO - O OBJECTIVO do autor neste artigo é descrever, de um ponto de vista micro, as articulações entre poder, censura e memória em Portugal, durante a fase final do regime do marquês de Pombal. Para tal, considera-se a produção da Real Mesa Censória, a instituição da censura que veio substituir o antigo sistema de censura tripartida em vigor durante mais de dois séculos. Através de uma viagem por algumas censuras do seu fundo documental, tenta ler-se a censura enquanto tentativa de controlar o que deve ser lembrado e o que deve ser esquecido, mas também a forma como deve ser lembrado e a forma como deve ser esquecido. Tenta também valorizar-se a censura enquanto documento que regista um trabalho intelectual, enquanto objecto de leitura e interpretação e enquanto parte de um diálogo mais vasto entre poder e cultura.

ABSTRACT - THE MAIN goal of this article is to describe in a detailed way the connections between power, censorship and memory, during the final stage of Pombal's regime. Its mains source are the written records of the Real Mesa Censória (Royal Censorship Board) the institution of censorship that Pombal created to replace the tripartite censorship that lasted for more than two centuries. A voyage to some of its reports will allow us to understand their reports as an attempt to control what should be remembered and what should be forgotten, but also in what ways it should be remembered or forgotten. Finally, these reports will be understood as documents that record an intellectual task; objects for reading and interpretation, and part of a broader dialogue between power and culture.

Rui Tavares é licenciado em História, variante de História da Arte, pela Universidade Nova de Lisboa e mestre em Ciências Sociais pelo Instituto de Ciências Sociais da Universidade de Lisboa. Prepara atualmente o seu doutoramento na École des Hautes Études en Sciences Sociales de Paris com um estudo sobre a censura literária nos países católicos (segunda metade do século XVIII), que se seguirá à tese de mestrado sobre a Real Mesa Censória sob Pombal (1768-1777), defendida em 1998.

O autor agradece a Ângela Barreto Xavier pela ajuda ao começar o texto, a Carla Araújo, que o ajudou a terminá-lo e a André Belo, Pedro Cardim e Angélica MuñosMelendez por suas sugestões e comentários

ESTUDOS AVANÇADOS manteve a ortografia e a sintaxe do autor. 